\title{
Enhancing English Vocabularies through Language Play in Children Movies
}

\author{
Eva Tuckyta Sari Sujatna (Corresponding Author) \\ Dept. of English, Faculty of Arts Universitas Padjadjaran \\ J1. Raya Bandung Sumedang km 21 Jatinangor, Sumedang Indonesia \\ Tel: 62-22-7796482 E-mail: evatuckyta@unpad.ac.id \\ Meita Lukitawati Sujatna \\ Department of English, Faculty of Languages Widyatama University \\ J1. Cikutra 204 A Bandung \\ Telp: 62-22-7275855 E-mail: meita.sujatna@widyatama.ac.id
}

Accepted: August 04, 2012 Published: September 15, 2012

Doi:10.5296/ijld.v2i5.2280 URL: http://dx.doi.org/10.5296/ijld.v2i5.2280

\begin{abstract}
Everybody either a child or an adult, likes playing. Playing is a fun activity. For children, watching movies is one of the fun activities. Learning languages can also be a fun activity by using language play. Language play can help the children in enhancing their ability in improving their vocabularies. In children movies, we usually found language play. The language play forms in children movies can be found both phonologically and morphologically forms. This article tries to explore the language play forms through children movies to support the children ability in enhancing their English vocabularies.
\end{abstract}

Keywords: Learning Language, Language Play

\section{Introduction}

English in Indonesia is one of the foreign languages. As one of the foreign languages, English learners in Indonesia only practice their English commonly in class. Generally, it is hard for the learners to communicate in English in their daily life (the outside of the class).

Learning English can be both formal and informal ways. Informal way that the present writers mean in this article is the learners can learn English informally by listening to the lyrics of songs, watching movies or reading books, novels, newspapers or magazines. By watching movies in English, Indonesian children can learn English informally; they not only can learn English through experiences but also can improve their vocabularies easily. 
In learning language (especially foreign language) the learners sometimes need their creativity in creating new ways to make the process of learning language become easier. Playing is one of the ways in learning. Not only children but also adults like playing. Playing is a fun activity.

Language play can be applied in learning foreign language as Cook (2000:182) mentions "provide a degree of support for the revival of activities which have fallen out of favor as dull, irrelevant, or artificial, and to suggest that they may be more enjoyable, useful and authentic than commonly believed." For children, watching movies is one of the fun activities. By watching movies, children can learn language easier than reading books. Besides sharpening their ability in listening they can also improve the number of their new vocabularies through watching movies as the fun thing.

According to Cook (2000: 150), "Learning has elements in common with both work and play (as they have elements in common with each other) but it nevertheless distinct from them." In other words, it can be said that they have a tight correlation among play, learning, and work as shown in the figure 1.

\section{Figure 1}

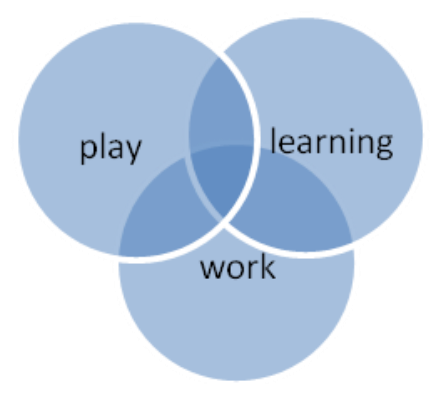

Play, learning, and work (Cook, 2000: 150)

In line with Cook (2000: 124) language play can be found in children's movies. The script writers try to represent the movies as both education and entertainments tools in the same time. The purpose of language play is to make the children's movies more creative and attractive. Here, the the language play is not the games, but it plays with the elements of the language itself. Through the language play, they try to enhance the children's vocabularies.

In learning language, a child has a tendency to shorten the utterance in words or phrases, in line with Fromkin et al. (2003) argues "Most children go through a stage in which their utterance consists of only one word..., because these one-word utterances seems to convey a more complex message". A two-year little girl utters "down" to mention "put down" or "sit down" or even tells to her parents that "my doll fell down". The little girl chooses to utter a short one rather than the complete one. The parents or the listener can understand the utterance because it can be described by the contextual meaning.

As a preliminary study, in this article, the present writers try to describe the phonological process and morphological process in language play to enhance English vocabularies through the children movies. The present writers hope the result of this research can bridge us as both the teachers and the students in improving our knowledge through language play in enhancing their English vocabularies. 


\section{Result and Discussion}

Language play that the present writers mention in this article refers to Crystal (1998) "We play with language when we manipulate it as a source of enjoyment, either for ourselves of for the benefit of others... We are, in effect bending and breaking the rules of the language. And if someone were to ask why we do it, the answer is simply: for fun." In line with the above argumentation, the present writers agree that the language plays with the elements of the language itself. According to Crystal, language play is for fun. It means that language play can help the learners to understand or to learn language easier. The learners can easily understand the utterance in the movies because it has been created for fun. As the function of the language itself, conventionally for communication, is sharing knowledge between the speakers and listeners. Sharing knowledge can be ideas, concepts, or even emotions.

Language play forms in children's movies can be phonological, morphological and semantic forms. Phonological point of view that the present writers mean in this article is alliteration. Alliteration, according to Crystal (1998) "- a use of language in which the words begin with the same initial sound/letter-though alliterative sequences never involve so many words at a time". The present writer finds phonological language play, as follows:

(1) Pay the bill or get the heel.

The example (1) shows that the word bill has the same rhyme with the word heel. The words bill and heel have different meaning, actually, but it has similar ending sound, the sound /bIl/ for bill and /hi:1/ for heel. The context of the utterance (1) is the speaker as the owner of the candy shop puts a notice on the wall. She wants to warn everybody who wants to take or taste the candy from her shop then they should pay the bill, not free of charge. If the customers don't obey it, they will get the heel. The word heel in this context is a high heel, which the owner of the shop always wears.

(2) A: Join the party?

B: Me too!

C: Me three!

The second example shows that it is a dialog among the three girls A, B and C. The first girl, A, asks Join the party? she means 'Will you join the party?' and the girl B replies Me too and the girl C responds Me three. The first utterance shows that the hearer (B) replies someone (A) offer by saying Me too she means 'I will join the party too' while the second hearer (C) responds Me three, she means the same answer with the first hearer 'I will join the party too', but she manipulates the words too/tu:/ which has similar sound with two /tu:/, then she made an answer three because three comes after two as numbers: one, two, three, etc.

(3) Honey Bunny Sweety

The expression honey bunny sweety is another example of language play. It shows that the first two words Honey and bunny have similar ending sound /i/, and both of them are nouns. The last word sweety in English is meaningless, but the speaker uses the word sweet and adds the sound /i/ to synchronize it to other words honey and bunny then the three words sound similar /i/. Related to the meaning honey means 'sweet sticky substance made by bees' and bunny means 'child's word for a rabbit' (as a cute animal for children) while sweety is meaningless and it derives from sweet means 'testing like sugar' or it is a noun, sweetie/swi:ti/, means 'to address someone we love'. So that, the three words has a tight meaning correlation among them, all refer to something sweet, then the speaker adds ending / $i$ / to make the sounds of the three words rhythmic. From the above three examples, the present writer concludes that the language play could be found phonologically. 
Besides phonologically, language play in children's movies can also be found morphologically. Words as the center of morphology are the main of this point of view. The present writers find several names of the characters in the movie based on their own characters, as follows:

(4) Brainy

Brainy as one of the characters in the children movie (The Smurf) is described as a clever smurf, and he is a nerd. The word brainy /brē-nē/ derives from brain. The word brainy has meaning 'having or showing a well-developed intellect' is an adjective is synonym with intelligent. the following is the tree diagram of the word brainy.

brainy (adj)

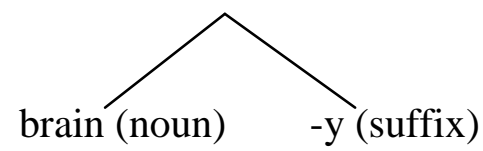

Not only Brainy but also Greedy, Grouchy, and Dreamy are the names that refer to the character of the owner of the name are adjectives which derive from nouns.

(5) Greedy

The word greedy /' gri:di/ is an adjective. The word greedy derives from the noun greed /gri:d/ (1) a strong desire for more food or drink than you need, or (2) a strong desire for more money, power, possession etc. than you need. It can refer to (1) wanting more food or drink than you need or (2) always wanting more money, possession etc. Based on the character described in the movie, the meaning refers to the first character, he always feels hungry, he always needs more food and drink than other smurf. The following is the tree diagram of the word greedy. greedy $(\mathrm{adj})$

(6) Grouchy

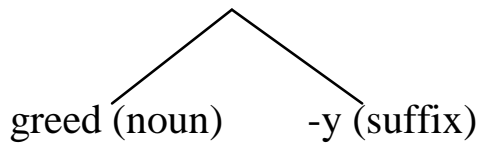

The word grouchy /' gravt $\int \mathrm{i} /$ 'a bad temper, especially you are tired' is an adjective. It derives from the noun grouch /gravt/ 'someone who is always complaining' as a noun. So that, the word grouchy as an adjective is derived from the noun grouch followed by the suffix $-\mathrm{y}$, as the following tree diagram.

grouchy (adj)

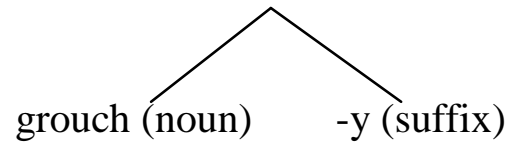

\section{(7) Dreamy}

The morphological process of the word dreamy is similar to the word brainy, greedy, and grouchy. The word dreamy /' dri:mi/ 'someone who is dreamy has a good imagination but it is not very practical' is an adjective. It derives from the word dream/dri:m/ 'asleep' as a noun. So that, the word dreamy as an adjective is derived from a noun dream and followed by suffix $-\mathrm{y}$, as the following tree diagram.

dreamy (adj)

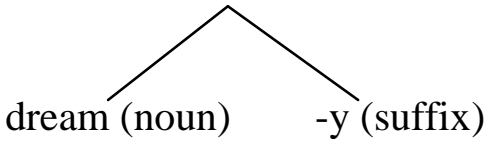


The four morphological processes of the words brainy, greedy, grouchy, and dreamy are called derivational process. The process involves the derivational morphology, according to Spencer and Zwicky (2001: 64), differs from inflectional morphology in that it provides new lexical names for objects, relations, and properties in the world.

\section{(8) Scaredy}

The present writers could not find the word scaredy in English vocabulary. The word is an analogy that refers to the word words explained, brainy and greedy. In English, there is a word scared /skerd/ as an adjective frightened of or nervous about something. The character of Scardy is described as a frightened smurf. To make sense of the word scaredy, it derives from the word scared as an adjective followed by the suffix $-\mathrm{y}$ (as brainy, greedy, grouchy, and dreamy do).

(9) Lazy

The word lazy /'leizi/ 'disliking work and physical activity, and never making any effort' is an adjective. The word lazy is similar to the words brainy, greedy, grouchy, and dreamy: they are adjectives. Besides the similarity, it has difference from the word mentioned. It is an adjective that does not derive from other word. So that, it has no tree diagram as shown by brainy, greedy, grouchy, and dreamy earlier.

Besides the derivational process as one of morphological processes, the present writers also find blending. Blend, in line with O' Grady et al. (1996: 706) a word that is created from parts of two already existing items, e.g. brunch from breakfast and lunch). Blending as one of the morphological process can be found as language play in children's movies as follows.

(10) It's so crunchious.

When the present writer consults to the dictionary, she could not find the word crunchious. The present writer finds that there are two possibilities in processing the word crunchious and both of them are blending. The word crunchious could be from crunch and delicious or from the word crunchy and delicious. In the present writer opinion, in parallelism thinking, she'd rather to choose crunchy and delicious than crunch and delicious, because crunchy and delicious both of them are adjectives while crunch is a noun and delicious is an adjective. Crunchy /' $\mathrm{kr} \Lambda \mathrm{nt} \int \mathrm{i} /$ 'food that is crunchy is firm and fresh, and make a noise when you bite it' is as an adjective. Delicious /dI'lIJəs/ 'very pleasant to taste and smell' is an adjective. The word crunchious can be described as a kind of food which is crunchy and delicious. The word crunchious is a blending of the word crunchy (from crunchy as an adjective) and -ious (from delicious as an adjective) as the following.
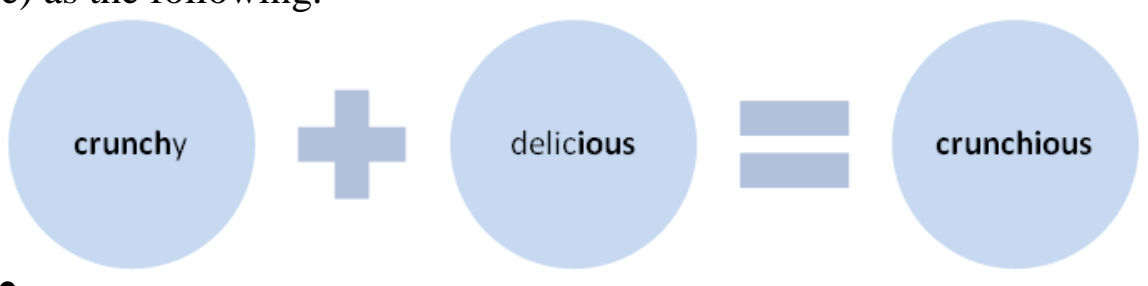

\section{Figure 2}

'Crunchious'

(11) frenemies (a title of a movie) 
The word frenemies (as a title of a movie) is also a blending. It is from the word friend and enemies. The word friend /frend/ 'someone who you like very much and like to spend time with' is a noun. The word enemies is a plural form of the word enemy /' enəmi/ 'someone who hates you and wants to harm you' is also a noun. Both of the words are blended becomes frenemies: fr- (from friend as a noun) and enemies (a plural form of enemy as a noun) as following.

\section{Figure 3}
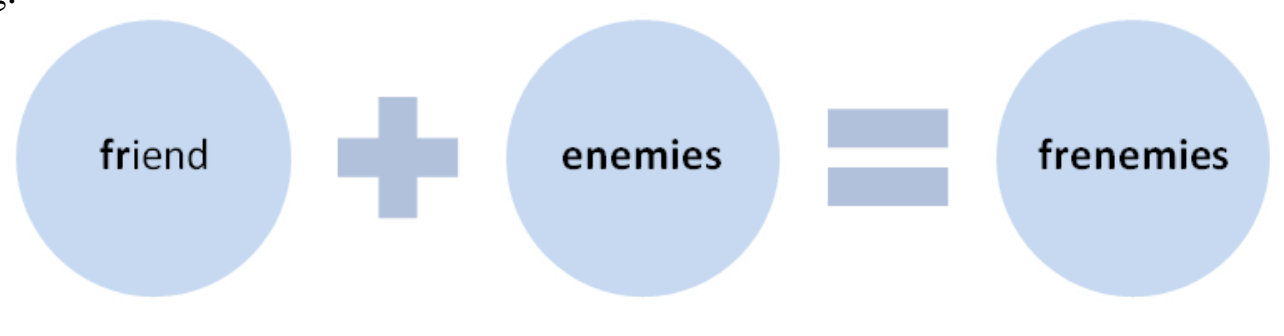

'Frenemies'

(12) No touchy!

The data (12) is an utterance of a four-year boy to his playmate. It is described that the boy forbids his playmate to touch his toy then he says No touchy. The utterance is shortened from Do not touch it (figure 4) while the word touchy is derived from touch and it as shown and figure 5 .

\section{Do not touch it!}

\section{No touchy}

\section{Figure 4}

Do not touch it => No touchy

Figure 3 shows that no touchy is formed from the shortened of the imperative sentence Do not touch it while touchy itself from touch + it, as shown in figure 4 .

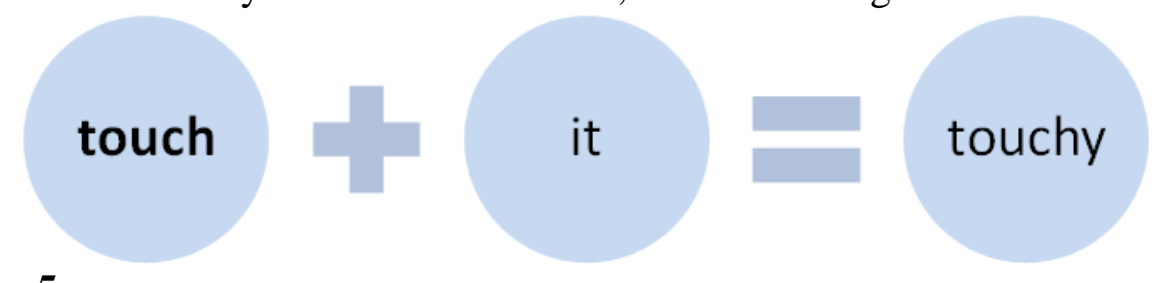

\section{Figure 5}

'touchy'

To understand the meaning comprehensively, the present writer consults the word touchy to the dictionary. The present writer finds that the word touchy has meaning "easily offended" as an adjective. Then the present writer compares the meaning based on the context. Finally, the present writer can conclude that the word touchy as verb (shortened from touch it) in the context has different meaning with the word in the dictionary as an adjective.

$$
\text { Oh my God that is so Clairious. }
$$


The word Clairious in utterance (13) is ambiguous. It could be an adjective (because it is preceded by degree word so) or a noun (it is written in capital letter as the beginning). Actually, the word Clairious refers Clair + hilarious as shown in figure 6 as follows.

\section{Figure 6}
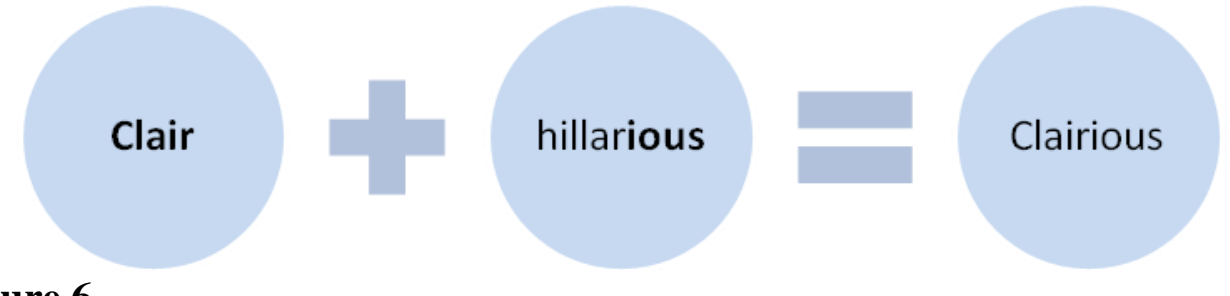

Clair + hilarious $=$ Clairious

The word Clairious is a blending from two words Clair (is a name) and hilarious (means very amusing) and the context of utterance says that Clair is very hilarious then it becomes Clairious. The word Clairious is used by Clair's friends to insult her.

\section{Conclusion}

Based on the early explanation, the present writer can conclude that the language play can be applied in learning (foreign) language. The language play in the children's movies can be found phonologically and morphologically derivational and blending) based on the context of the utterances. By understanding and applying language play, it can help the young learners in learning foreign languages.

\section{References}

Aronoff, Mark \& Fudeman, Kirsten (2005) What Is Morphology? Carlton: Blackwell Publishing

Cook, Guy (2000) Language Play, Language Learning. New York: Oxford University Press. Crystal, David (1998) Language Play. England: Penguin Books Ltd.

Fromkin, et al. (1988) An Introduction to Language. (Second Australian edition). Sydney: Holt Reinhart and Winston

Katamba, Francis (1993) Morphology. London: The Macmillan Press Ltd.

Leech, et al. (2003) An A-Z of English Grammar \& Usage. Harlow: Pearson Education Limited O'Grady, et al. (1996) Contemporary Linguistics. Harlow: Addison Wesley Longman Limited Spencer, Andrew and Zwicky, Arnold M. (2001) The Handbook of Morphology. Malde: Blackwell Publishers 